\title{
Al-Pac Catchment Experiment (ACE)
}

\author{
by Margaret Donnelly ${ }^{1}$, Kevin J. Devito ${ }^{2 *}$, Carl Mendoza ${ }^{3}$, Richard Petrone ${ }^{4}$ and Mark Spafford ${ }^{5}$
}

\begin{abstract}
The Al-Pac Catchment Experiment (ACE) was initiated in 2005 to examine the influence of aspen harvest and linear disturbances on water and energy movement in Boreal Plain (BP) ecosystems. A paired, pre- and post- harvest experiment in aspen-dominated stands was conducted on two meso-scale $\left(10-20 \mathrm{~km}^{2}\right)$ stream catchments with a range of surficial geology and low relief. Comparing flow two years pre-harvest and three years post-harvest indicated no observable differences in low and high flow discharge or geochemistry concentrations between reference and harvested catchment outflows. Reduced evapotranspiration in harvested relative to references catchments was short lived. Soil and groundwater storage buffered the impacts of harvesting on catchment stream flow and large time lags of up to four years were observed in initial response. Due to the low relief, deep and variable surficial geology and storage potential interacting with seasonal and decadal wet and dry patterns, measures of changes in (and indices of) soil moisture or groundwater recharge and storage are more meaningful than stream flow in assessing hydrologic recovery following harvesting. This study has been incorporated into hydrogeological framework to develop effective planning tools that can be used to maximize harvesting and hauling efficiencies.
\end{abstract}

\section{RÉSUMÉ}

Le bassin versant expérimental d'Al-Pac (ACE) a été créé en 2005 avec pour objectif détudier l'influence de la récolte du peuplier et des perturbations linéaires sur les mouvements de l'eau et de l'énergie dans les écosystèmes de la plaine boréale (BP). Nous avons effectué des essais jumelés, avant et après récolte, dans des peuplements à dominance de peuplier situés dans des bassins versants d’étendue moyenne $\left(10-20 \mathrm{~km}^{2}\right)$ présentant une variété de dépôts de surface et un relief peu accidenté. La comparaison de lécoulement enregistré les deux années avant la récolte avec celui des trois années après la récolte n’a pas révélé de différence notable dans les débits de faible et de haut niveau ni dans la concentration des éléments géochimiques entre le bassin versant de référence et celui qui avait été exploité. La baisse de lévapotranspiration dans les bassins exploités par rapport aux témoins n’a été que de courte durée. Les réserves du sol et souterraines ont tamponné les effets de la récolte sur le débit des bassins versants, et on a pu observer des temps de réponse importants allant jusquà quatre ans avant d'en ressentir les premiers effets. En raison du relief peu accidenté, de dépôts de surface profonds et variables, et du potentiel de stockage qui interagissent avec les alternances de périodes humides et sèches saisonnières et décennales, il appert que la mesure des changements au niveau (et de ses indices) de l'humidité du sol ou de la recharge et de la réserve d’eau souterraine donne une représentation plus fiable du rétablissement hydrologique après récolte que la mesure du débit des cours d'eau. Les résultats de cette étude ont été intégrés dans un cadre hydrogéologique permettant de concevoir des outils de planification pour maximiser l'efficacité de la récolte et du transport.

\section{Introduction}

Alberta-Pacific Forest Industries Inc. (Al-Pac) primarily utilizes trembling aspen (Populus tremuloides Michx.) and balsam poplar ( $P$. balsamifera L.) in their forestry operations in the western boreal forest. The use of aspen is relatively new, as forestry companies only began widespread usage of aspen in pulp and oriented strand board production in the 1980s (Johnson and Miyanashi 2008). Thus, the relative impact of harvesting aspen (a clonal species) on water and energy flow, at both small and large scales, is not well understood.

To this end the Al-Pac Catchment Experiment (ACE) was initiated in 2005 to examine the influence of aspen harvest and linear disturbances on water and energy movement in Boreal Plain ecosystems, and to provide information on the influence of scale of cut on timing and magnitude of stream runoff and water quality (Devito et al. 2012; Table 1, Fig. 1). A paired, pre- and post- harvest experiment in aspen-dominated stands was conducted on two meso-scale $\left(10-20 \mathrm{~km}^{2}\right)$ stream catchments with a range of surficial geology, and three small tributaries $\left(\sim 1 \mathrm{~km}^{2}\right)$ with differing soil textures (Table 2). This followed an earlier Moose Lake catchment $\left(0.5 \mathrm{~km}^{2}\right)$ study where post-harvest aspen vs. non-harvest sub-catchments were examined. This study illustrated the influence of soil moisture, groundwater storage, and climate variability on threshold runoff responses (Devito et al. 2005a, 2005b).

$\mathrm{Al}-\mathrm{Pac}$ is committed to an ecosystem-based approach to sustainable forest management using the natural disturbance (ND) model, whereby forest harvest patterns are designed to resemble patterns similar to natural disturbances. Specifically,

\footnotetext{
${ }^{1}$ Forest Ecologist, Environmental Sciences, Alberta Pacific Forest Industries Inc., Edmonton, AB

${ }^{2}$ Department of Biological Sciences, University of Alberta, Edmonton, AB, Canada; ${ }^{\star}$ corresponding author: kdevito@ualberta.ca

${ }^{3}$ Department of Earth and Atmospheric Science, University of Alberta, Edmonton, AB

${ }^{4}$ Department of Geography and Environmental Management, University of Waterloo, Waterloo, ON

${ }^{5}$ Little Fish Consulting Ltd., Athabasca, AB
} 


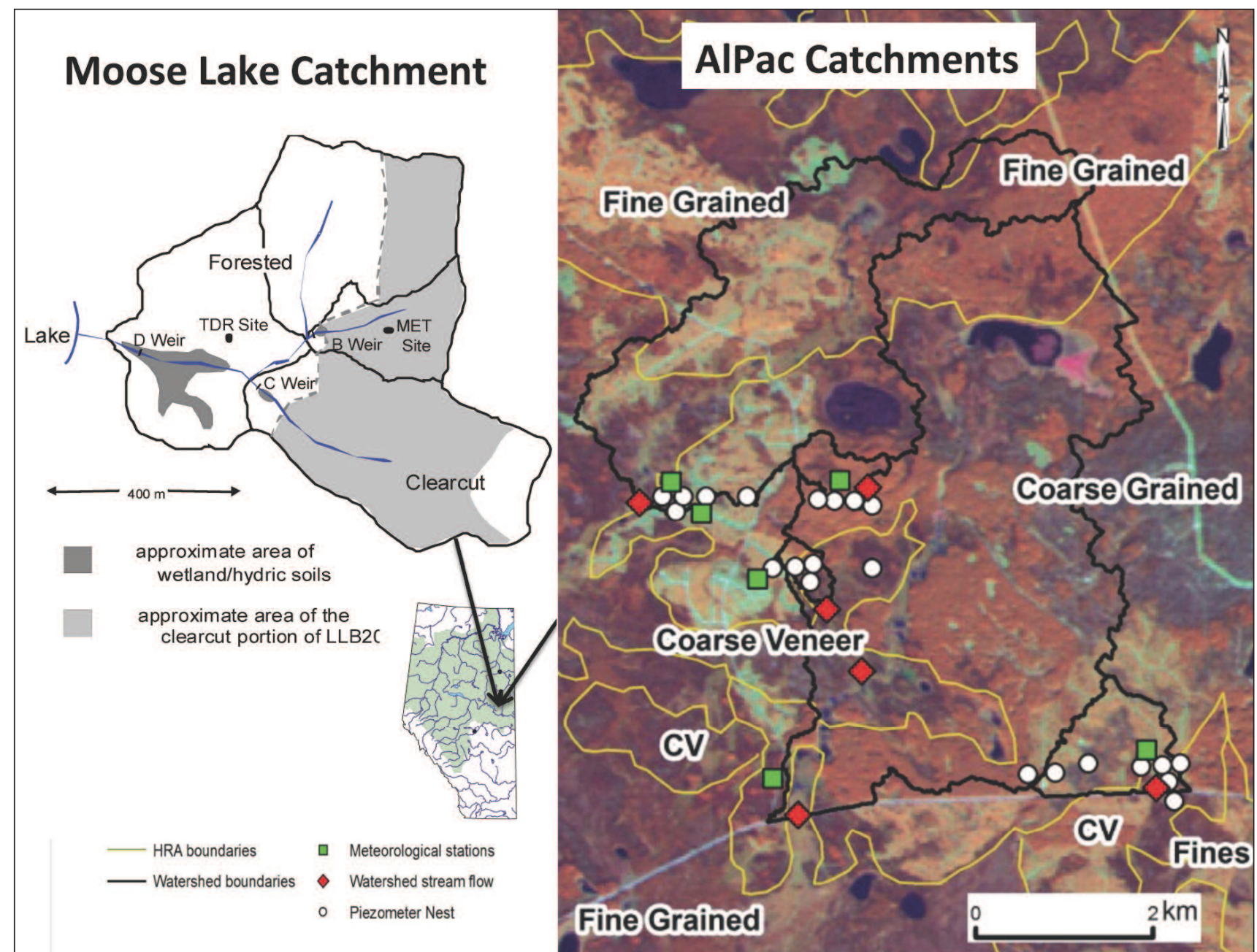

Fig. 1. ACE study watershed showing meteorological and hydrometric gauging stations.
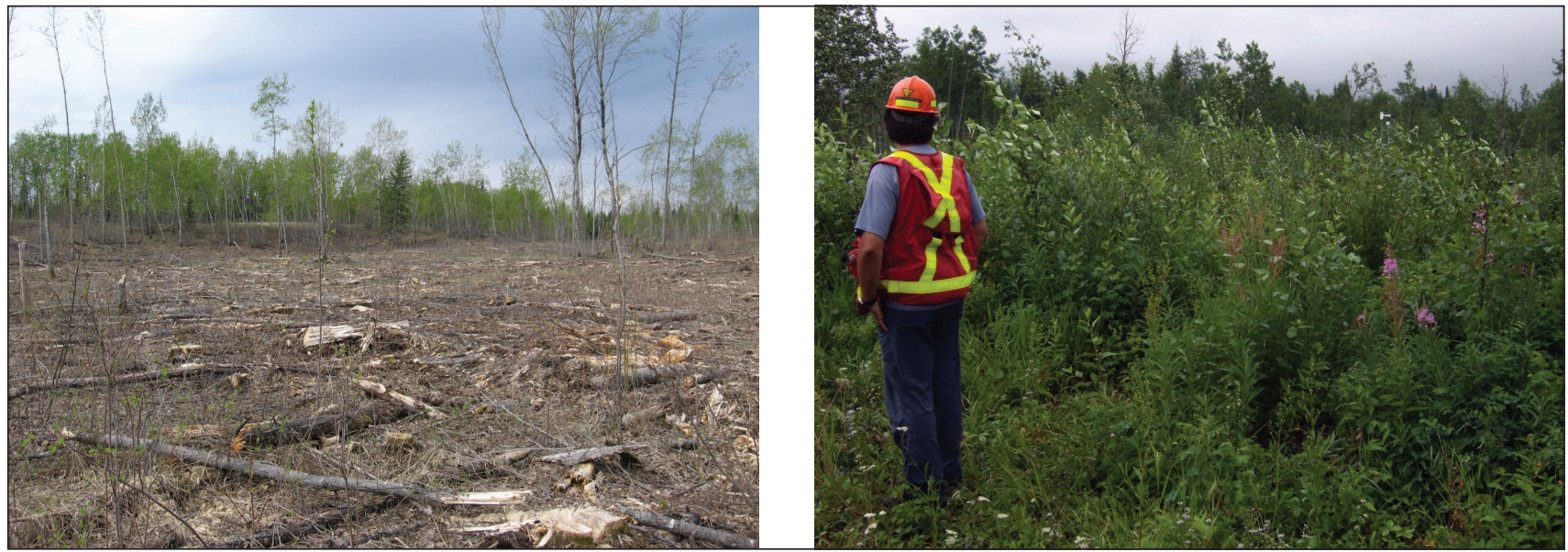

Fig. 2. Left (a): fall harvesting (May 2006); Right (b): aspen regeneration in second growing season (July 2008). 
the ND model creates larger disturbance events that are an aggregation of smaller harvest patches and fewer roads, rather than discrete, smaller-sized clear cuts $(<$ 500 ha in size) with extensive road networks. These larger disturbances are designed to promote heterogeneity in future forest landscapes, including many attributes that differ from historic approaches to forest management. These include the retention of mature forest areas within and between harvest areas, irregularly shaped boundaries and a range of disturbance sizes (up to thousands of hectares in size). As part of this approach, the $2006 \mathrm{Al}$-Pac Forest Management Plan proposed to concentrate harvest activities in a given area for a 10-15 year period resulting in larger disturbance events with unknown effects on the hydrologic processes at a catchment or landscape scale.

The regional moisture deficit $(\mathrm{P} \leq \mathrm{PET})$, large spatial heterogeneity of deep glacial deposits (outwash sands to lacustrine clay), and seasonal and decadal wet and dry cycles in the boreal plains region (Devito et al. 2005c) result in: a) dynamic and complex surface and groundwater interactions; and, b) potentially large temporal and spatial variability in the sensitivity of forest and stream ecosystems to local and regional disturbance (Devito et al. 2005a, Macrae et al. 2005, 2006; CarreraHernandez et al. 2011a, 2011b).

Thus, hydrologic research on the boreal plains has demonstrated an increasing need for spatially explicit modeling and visualization tools. These tools are needed to assess the cumulative effects of aspen harvest and linear disturbance, and to predict hydrologic outcomes (Spafford and Devito 2005).

\section{Results}

This study is closely associated with HEAD2 Aspen Harvest and Recovery study at the Utikuma Region Study Area (URSA), and combined with the Moose Lake Catchment Study (Devito et al. 2005a, 2005b; Macrae et al. 2005, 2006) will provide information on the influence of scale and surficial geology on Boreal Plain ecosystem responses to aspen harvest and post-harvest recovery (Table 2):

- Hydrometric, geochemical, and isotopic sampling and analyses of reference and experimental catchment balances show that partitioning of baseflow and storm surface flow is a function of the distribution of precipitation in time (e.g., snow vs. rain) and the interaction with antecedent moisture (Devito et al. 2005a, 2005b);
Research design

Catchment hydro-chemical response and water balance, internal process studies

ACE: $36.3 \%$ aspen harvest

Moose Lake Catchment: aspen partial-harvest of catchment

ACE: before and after treatment with unharvested reference catchments Moose Lake: unharvested tributaries

ACE Soil moisture, Groundwater: 2005 - present

Moose Lake Catchment: 1997-2001

Stream flow and chemistry; energy balance and meteorological sites; snow, soil moisture and nutrient distribution; surface depression storage; shallow groundwater; hydrogeology; leaf area

- Comparing flow two years pre-harvest and three years post-harvest indicated no observable differences in low and high flow discharge or geochemistry concentrations between reference and harvested outflow streams of both the smaller and larger catchments;

- Although aspen harvest resulted in increased soil moisture in experimental catchments, the excess water was largely absorbed into deep fine-grained moraine substrates and resulted in groundwater recharge. There was little or no lateral flow to adjacent wetlands and aquatic systems and little increase in the probability of runoff responses (Carrera-Hernandez et al. 2011a, 2011b);

- Comparisons of outflows with soil moisture, groundwater, and surface depression response and geochemistry indicate that most stream flow is generated from wetland areas, and soil storage dominates in the forested hydrologic units;

- Both climate signals and modifications of flow by beaver dominate the runoff regime and potentially mask any difference due to harvesting and must be considered in evaluating forestry practices; 
- Reduced actual evapotranspiration (AET) in harvested relative to references catchments is short-lived (Fig. 2). Soil and groundwater storage buffer the impacts of harvesting on catchment stream flow;

- Comparison of snow and soil moisture transects between reference and harvested catchments indicate little snow redistribution and show a strong relationship between soil moisture and leaf area index (LAI) following harvesting;

- Linear (i.e., seismic lines), road, and landing disturbances where vegetation is largely removed and little sucker regeneration occurs show increased soil moisture and increased probability of recharge three years following harvest. These areas represent a small proportion of the harvested area; and,

- Monitoring of potential evapotranspiration (PET) in relation to catchment hydrology and vegetation dynamics clearly shows the limitations of using stream flow alone. Changes in AET are not correlated to runoff responses. Consideration of soil moisture and groundwater storage is required in assessing and modeling the recovery of AET changes in this landscape.

\section{Management/Operational Results}

Complete water balance measurements and field studies of key processes (pre- and post-harvest) have been integrated with numerical modeling to confirm the conceptual model for stream flow or run-off. The model demonstrates that lateral hill slope runoff or stream flow may not be an appropriate indicator (or index) of the response to land use or climate cycles assumed in many BMPs and policies. Given research and modeling results, and the variability in surficial geology and storage potential in these landscapes, measures of changes in (and indices of) soil moisture or groundwater recharge and storage are more meaningful in assessing hydrologic recovery following harvesting (Devito et al. 2012);

- Coupling field AET measures with Hydrogeosphere (HGS) modeling using the previous 90-year climate data indicates a time lag in initial response and that the impact of aspen harvest on soil moisture regimes and groundwater recharge may take up to four years to manifest, but is largely only observed if harvesting occurs during a wet cycle when the potential to exceed soil moisture storage exists (Carrera-Hernandez et al. 2011a); and,

- This study has been incorporated into hydrogeological framework (Devito et al. 2005) for the BP to initiate the development of effective planning tools that can be used to maximize harvesting and hauling efficiencies (Spafford and Devito 2005).

\section{Acknowledgments}

We acknowledge assistance by Kevin Smith and Julienne Morissette, Ducks Unlimited Canada, and Alberta Geologic Survey. Support provided by Ducks Unlimited Canada Boreal Program, Wetland and Waterfowl Research (IWWR), Syncrude Canada Ltd (\#4410012045), and NSERC-CRD (CRDPJ 238050-00).

\section{References}

Carrera-Hernandez J.J., C.A. Mendoza, K.J. Devito, R.M. Petrone and B.D. Smerdon. 2011a. Effects of aspen harvesting on groundwater recharge and water table dynamics in a subhumid climate. Water Resour. Res. 47, W05542. doi:10.1029/2010WR009684.

Carrera-Hernandez, J.J., C.A. Mendoza, K.J. Devito, R.M. Petrone and B.D. Smerdon. 2011b. Effects of aspen harvesting on groundwater recharge and water table dynamics in the Western Boreal Forest. 63 p. Alberta-Pacific Forest Products, Report, April 2011

Devito, K.J., I.F. Creed and C. Fraser. 2005a. Controls on runoff from a partially harvested aspen forested headwater catchment, Boreal Plain, Canada. Hydrol. Process. 19: 3-25.

Devito, K.J., C.J.D. Fraser and I.F. Creed. 2005b. Climate and runoff characteristics of a Boreal Plain headwater catchment, Lac La Biche, AB, Canada: Implication for forest management. Sustainable Forest Management-NCE report.

Devito, K.J., I. Creed, T. Gan, C. Mendoza, R. Petrone, U. Silins and B. Smerdon. 2005c. A framework for broad scale classification of hydrologic response units on the Boreal Plain: Is topography the last thing to consider? Invited Commentaries, HP Today, Hydrol. Process. 19: 1705-1714.

Devito, K., C. Mendoza and C. Qualizza. 2012. Conceptualizing water movement in the Boreal Plains. Implications for watershed reconstruction. Synthesis report prepared for the Canadian Oil Sands Network for Research and Development, Environmental and Reclamation Research Group. 164 p. http://hdl.handle.net/ 10402/era.30206.

Johnson, E.A. and K. Miyanishi. 2008. Creating new landscapes and ecosystems: The Alberta Oil Sands. Ann. N.Y. Acad. Sci. 1134: 120-145.

Macrae, M.L., I.F. Creed, E. Mcdonald and K.J. Devito. 2006. Relation of soil nitrogen distribution and surface and ground water nitrogen concentrations in a partially harvested boreal plain aspen catchment. Can. J. For. Res. 36: 2090-2103.

Macrae, M.L., T. Redding, I.F. Creed, W. Bell and K.J. Devito. 2005. Soil, surface water and groundwater phosphorus relationships in a partially harvested Boreal Plain aspen catchment. For. Ecol. Manage. 206: 315-329.

Spafford M. and K. Devito. 2005. Boreal Conservation Hydrology and Forestry in the Alberta-Pacific FMA area. Alberta Pacific White paper, Report. $25 \mathrm{p}$. 